\title{
DIE BETEKENIS VAN DIE WYSGEBEERTE VIR DIE AKADEMIESE EN PERSOONLIKE VORMING VAN DIE STUDENT
}

\author{
Prof. dr. M. Elaine Botha
}

Dept. Wysbegeerte en Wetenskapsleer, PU vir CHO.

Die aktualiteit van ons tema kan aan verskillende faktore toegeskryf word. Nie alleen speel die eeue-oue stryd tussen die wetenskappe en die Wysbegeerte ' $n$ rol nie, maar in die toenemende professionalisering van die universiteit kom die sogenaamde vormingsvakke, waaronder Wysbegeerte, se bestaansreg en voortbestaansreg direk in gedrang. Die pragmatiese benadering deur studente (en dosente) oor waarheen (d.w.s. na watter beroep) 'n besondere kursus lei, kan nie meer skouerophalend eenkant toe geskuif word nie, so asof filosowe drommers is oor 'n ander wêreld.

Die antwoord wat ons elkeen gaan gee op ons probleemstelling sal egter uiteenlopend wees omdat ons tema die saamknooppunt is van ' $n$ hele aantal aspekte waarin die ontologiese, antropologiese en wetenskapsteoretiese uitgangspunte in berekening gebring word en moet word.

Met ons tema hang ook die vraag direk saam na die wese en funksies van die verskynsel wat ons ' $n$ universiteit noem, maar wat soms gekarakteriseer is as 'n karavaan en somtyds as 'n "merry-go-round". Maar dit hang ook saam met die samehang en onderskeid van die wetenskappe, met die student as akademikus en as mens in die veelheid van sy potensiële roepinge. Daarby kom nog die moontlikhede van ten minste twee benaderinge naamlik die sisisteembenaderingsmetode of die probleembenaderingsmetode. Met die eerste kan jy by die verste omtrek van raakpunte van jou tema begin en steeds nader na die middelpunt van die tema beweeg. Met die probleembenaderingswyse begin jy eerder met die mees voor-die-handliggende sake wat teen jou opspring om vandaar te beweeg na die sisteen. Ons gaan hier volgens die probleembenaderingswyse te werk gaan, maar erken die legitimiteit en selfs die noodsaaklikheid van die ander benaderingswyse wat bv. die ontologiese, antropologiese en wetenskapteoretiese eers stel en dit dan toepas op die probleem.

\section{Die student en die universiteit}

Dit is nie ons bedoeling om ' $n$ volledige handeling van die universiteit as samelewingsverband hier te gee nie. Maar dit is tog belangrik dat ons duidelikheid kry oor die taak en funksies van die universiteit ten einde die plek van Wysbegeerte aan die universiteit in sig te kry.

Daar is verskillende omskrywings gegee oor die funksies van die 
universiteit. (Kerr, 1979, p. 8, e.v.) noem bv. 10 sodanige funksies op wat ons soos volg saamvat:

- Onderwys en opvoeding met die oog op 'n kulturele agtergrond

- Professionele onderwys

- Voortgesette onderwys

- Navorsing

- Diens aan die gemeenskap

- "Talentejag"

- "Child care" (sielkundige dienste)

- Aanleer van 'n kritiese instelling

- Diens vanuit gebondenheid aan die "establishement".

Ortegy Y Gasset (1946, p. 48) noem veral drie funksies te wete die oordrag van kultuur, professionele opleiding en navorsing waarmee verbind word die opleiding van nuwe wetenskaplikes.

Nieteenstaande die baie variasies op die tema lyk dit nog vir ons die beste om die taak van die universiteit te omskryf as die opleiding van wetenskaplikes binne ' $n$ opvoedkundige konteks en dan kan daar veral drie funksies nader omlyn word, naamlik:

die oordrag van kennis as doseertaak;

die ontginning van nuwe kennis as navorsingstaak; en

die vorming van die student deur middel van wetenskapsbeoefening as opvoedingstaak.

Daarby kan vanselfsprekend nie die diens aan die gemeenskap buite rekening gelaat word nie, maar dit is veelmeer die gevolg en vrag van die werk van die universiteit as sy besondere taak. Diens aan die gemeenskap kan immers ook van die staat, die gesin, die huwelik, die kerk ens. verwag word.

Daarby word dit gou duidelik dat wetenskapsbeoefening veral die middel is wat die universiteit gebruik om sy funksies te vervul. Die universiteit wil wetenskaplikes oplei sodat hulle in die vervulling van die verskillende roepinge waarin hulle gaan staan, w.o. professionele en beroepsroeping, op wetenskaplike wyse diens kan verrig.

Hierin sluit die universiteit as tersiêre onderwysinrigting aan by die primêre en die sekondêre. Waar die primêre onderwys veral empiries van aard is en die sekondêre onderwys veral geneties van aard is, daar is die tersiêre onderwys veral filosofies van aard omdat daar op hierdie vlak besinning bestaan oor die grondstruktuur van kennis, oor die seleksie van sekere metodes, die evaluering van teorieë en die ontwerp van nuwe teorieë 
en modelle en dit by elke wetenskap. By die universiteitsonderwys gaan dit nie slegs om sogenaamde kennis van die feite nie, maar juis om die verstaan en verklaar en begryp waarin die konteks en perspektiewe vanuit die werklikheidsbeskouing onontbeerlik is.

Daarby moet die opvoedkundige of agogiese taak van die universiteit geintegreer word. Hierdie opvoeding is meer as peda-gogies omdat die student gewoonlik in sy adolessente jare is, maar die middel waarmee die universiteit sy agogiese taak verrig is juis die wetenskapsbeoefening. Daarom word die hele persoonlikheid van die student onderwerp aan hierdie leiding en kom sy beroep in sig, maar ook die oordrag van kultuur. Eensydige professionalisering van die universiteit waarin alle klem op die beroepsopleiding gelê word, verlaag die universiteit se status tot 'n ekonomiese hoërskool en hou nie rekening met die eenheid van die menslike persoonlikheid nie. Hierdie antropologiese uitgangspunt is na my mening grondliggend aan die universitêre opvoedingstaak. Wie meen dat hy alleen die intellektuele ontwikkeling van studente aan die universiteit moet bevorder, versnipper en fragmenteer die eenheid van die persoonlikheid van die student. Maar weer eens beklemtoon ons die wetenskapsbeoefening by uitnemendheid die middel is vir die vorming van 'n geintegreerde persoonlikheid. Die aankweek van 'n wetenskaplike houding en styl is in hierdie verband dus belangrik.

Maar juis omdat die universiteit as tersiêre onderwys- en opvoedingsinrigting die hele persoonlikheid van die student moet ontwikkel deur middel van die wetenskapsbeoefening, dit wil sê dosering en navorsing, is die gemeenskapskarakter van die universiteit van grondliggende betekenis.

Die universiteit is 'n gemeenskap van wetenskaplikes en die wetenskaplikes is nie slegs en alleen die dosente nie, maar ewe-eens die studente. Die gemeenskap word egter saamgebind deur sekere ideale. Daarom moet dit die voorreg en reg van elke universiteit wees om self sy eie karakter en beleid te bepaal en kan met die 1916-wet op universiteite in S.A. nie vrede gevind word nie, omdat daarin dié reg en voorreg van die universiteite weggeneem word.

Hierdie gemeenskaplike uitgangspunte en ideale funksioneer vir ' $n$ baie groot deel as interne stuurfaktore in die wetenskapsbeoefening (Radnitzky), maar sluit ook die lewensbeskoulike begronding in waaronder 'n eie siening van die werklikheid en die mens.

Die relevansie van Wysbegeerte is in hierdie verband voor-die-hand-liggend, juis omdat Wysbegeerte ook gesistematiseerde lewens- en wêreldbeskouing is wat die totaliteit en samehang van die werklikheid bestudeer. En dit is juis hierdie werklikheid waarin die wetenskappe geinteresserd is as studievelde. 


\section{Wysbegeerte en die wetenskappe}

Ons moet die verhaal oor die afgrensing van wetenskap van Wysbegeerte of ook Metafisika maar met die Positivisme begin. Nie alleen het Comte die drie stadia onderskei tussen die teologiese, matifisiese en die positiewe nie, maar die afgrensing van wetenskap teenoor pseudo-wetenskap en metafisika is tradisioneel in die kringe van die Logiese Positivisme steeds gevoer vanuit die kriterium van induksie en verifieerbaarheid as kenmerke van wetenskap. Terloops moet opgemerk word dat Feuerbach, onafhanklik van Comte, reeds onderskei het tussen die teologiese, metafisiese en wat hy genoem het, wetenskaplike fase in die geskiedenis van die ontwikkeling van wetenskap. Ons wil kortliks na die standpunt van drie figure kyk naamlik Popper, Aggassi en Wartofsky.

Die probleem van "demarcation" word deur Popper (1968, p. 34) "Kant's problem" genoem en die probleem van induksie "Hume's problem" en tereg verbind Popper die twee probleme aan mekaar. Die empirisme van Hume het die positiviste verlei om aan die induktiewe metode alleenheerskappy te verleen en dit het aanleiding daartoe gegee dat Metafisika vanweë sy aard dan "meaningless" en "nonsensical" is en daarmee probeer die positivisme eintlik om Metafisika oorbodig te verklaar. Daarby kom dan dat die Metafisika in hul oë ipso facto spekulatief is. Popper gaan dan in op Wittgenstein se onderskeiding tussen waar, valse en betekenislose stellings en coon dan aan dat Wittgenstein inderdaad die Wysbegeerte van sy bestaansreg beroof het en dit laat oorloop het in die taalanalise waardeur taalkundige "puzzles" ondersoek word omdat daar geen werklike filosofiese probleme bestaan nie.

Popper (1952, p. 130) toon dan aan dat "genuine philosophical problems are always rooted in urgent problems outside philosophy, and they die if these roots decay". Hierin wys hy tereg na die interafhanklikheid van die Wysbegeerte en die wetenskappe. Agassi kom later hierop terug as hy Popper se tema omdraai na: "The nature of scientific problems and their roots in science."

'n Tweede belangrike les wat ons by Popper kan leer is dat die prima facie-metode van dosering van Wysbegeerte grotendeels bydra vir die lae profiel van Wysbegeerte in die universiteite. Die prima facie-metode is dan dat studente direk met die groot filosowe se werke aan die gang kom. En dan lees hulle die antwoorde wat die filosowe gee en hulle weet nog nie wat die vrae is wat op ' $n$ antwoord wag nie. Daarom is Wysbegeerte vir baie mense "meaningless" en "non-sensical". Popper wil daarenteen dat Wysbegeerte net soos die wetenskappe hulle moet besin oor probleme en daarop roep hy uit: "We are not students of subject matter but students of problems" (Popper, 1952, p. 125).

Popper bring beswaar in teen die standpunt van die Logiese Positivisme 
en soek na 'n ander kriterium vir die wetenskap in plaas van induksie en verifikasie. Hy vind dit dan in falsifikasie wat die toetsbaarheid veronderstel. Hy stel dit onomwonde: "Now in my view there is no such thing as induction. Thus inference to theories, from singular statements which are 'verified by experience' (whatever it may mean) is logically inadmissable. Theories are, therefore, never empirically verifiable" (Popper, 1968, p. 40).

Die vraag is of Popper inderdaad verby die Positivisme kom. Wartofsky (1967, p. 111) meen van nee: "If the positivist attempts to eliminate metaphysics fails because its verificationist demarcation between sense and nonsense fails, so too does Popper's attempt to effect a demarcation on falsificationist grounds. The failure is instructive; for what Popper does is, in effect, to modify positivism, to broaden its conception of what counts as meaningful ... But the old Adam of positivism is still in him, with the effect that although he recognizes the heuristic and methodological value of the metaphysical tradition, he cannot account in any substantive way for why it should have this value". Ook vir Popper is die metafisika egter nie egte wetenskap nie, omdat dit nie toetsbaar of falsifiseerbaar is nie. Metafisiese teorieč mag waar of vals wees, maar dit is in beginsel onmoontlik om dit vas te stel (vgl. Koningsveld, 1977, p. 94).

'n Tweede figuur wat vir ons onderwerp interessant is, is Joseph Agassi, veral soos dit in sy relevante studie na vore kom met die titel: The nature of scientific problems and their roots in metaphysics. Hy beskou Metafisika as "a co-ordinating agent" in die wetenskaplike navorsing en stel dan die teorie op dat die wetenskaplike navorsingsprojekte ten nouste saamhang met sekere metafisiese probleme. Die metafisika voorsien selfs na sy mening die raamwerk vir die wetenskap, en wel in interpretatiewe sin. Wetenskaplike teorieë kan vanuit verskillende metafisiese gesigspunte verskillende geinterpreteer word. Net soos Popper wil hy ook ingaan teen die positivistiese verwerping van metafisika as non-sense, en herlei hierdie standpunt terug na Francis Bacon wat die twee metodes induksie en spekulasie onderskei het en dienooreenkomstig die induksie vir wetenskap gereserveer het en die spekulasie vir metafisika. Hy vind nouer aansluiting by Whewell wat ook goeie metafisika as 'n kenbron vir die wetenskap behou het. "I suggest the theory that significance with respect to (pure) science is usually significance with respect to science's metaphysical frameworks". (Agassi, 1964, p. 210).

Agassi verander die begrensingskriterium van Popper sodat volgens hom die doel van navorsing nie die toetsing van toetsbare hipoteses is nie, "but rather the finding and testing of metaphysically relevant hypotheses" (Wartofsky, 1967, p. 144). En so wil Agassi dan dat die Metafisika leiding- 
gewend laat optree in die keuse tussen toetsbare teorieè en hy wil selfs so ver gaan om te sê dat Metafisika en metafisiese probleemstellings navorsing inisieer en stimuleer. Tog hou hy vol dat Metafisika nie-wetenskaplik is (Agassi, 1964, p. 198).

'n Derde belangrike kontemporêre figuur is Marx Wartofsky. In 'n belangwekkende artikel, Metaphysics as heurtistic for science, toon hy die onhoudbaarheid van die standpunt van die Logiese Positivisme met hul nadruk op . induksie en verifikasie aan en die gepaardgaande verbanning van Metafisika. Hy meen selfs dat Popper en Agassi (asook Kuhn) nie ver genoeg gaan wanneer hulle oor die verhouding van Metafisika en wetenskap spreek nie. In hierdie verband is dit belangrik dat die probleemstelling volgens Wartofsky juis moet wees. Die probleem is nie of Metafisika invloed uitoefen in wetenskap nie, soos veral deur Popper en Agassi gestel nie, maar waarom Metafisika 'n bepaalde invloed uitoefen. Hy sê: "The task at hand is not to describe the relation between metaphysics and science, but to explain it" (Wartofsky, 1967, 1949). Hy maak dan 'n belangrike punt daarvan dat Metafisika leidinggewend vir die verstaan in die wetenskap is omdat in elke wetenskap 'n ondersoek na die konsepsuele grondslae en agtergronde veronderstel word. En onder Metafisika wil hy dan juis verstaan "any systematic critique of the conceptual foundations of science" (p. 152). Terselfdertyd argumenteer hy dat die afskaffing of verdwyning van Metafisika gelykstaan aan die afskaffing of verdwyning van rasionaliteit en daarom gaan dit veral om die bydrae van die Metafisika in die teoretiese "verstaan".

Maar dan gaan hy'n stap verder en beweer dat vir teoretiese of wetenskaplike "verstaan" dit nodig is dat die "story" of die hele verhaal begryp word en hierdie storie of verhaal funksioneer as 'n konsepsuele raamwerk met sy eie sistematiese struktuur, sy verwysings of referensie en sy abstrakte weergawe: "The story represents the first and most pervasive conceptual model in our experience" (p. 157). Dat sodanige konsepsuele raamwerke gebruik word, is na my mening onvermydelik en daarom is selfkritiek steeds noodsaaklik. Maar aan die hand waarvan moet hierdie selfkritiek teenoor die konsepsuele raamwerk gedoen word? En dit is juis hier waar die Metafisika meta-modelle voorsien (p. 158) wat leiding gee in die evaluering van die raamwerk. En hier weer gaan dit oor die vraag of sodanige metafisiese meta-model waar of vals is, waarom vir die een gekies word en nie vir die ander nie. Dit berus dan op dieper oortuigings aangaande die een werklikheid. En ook oor hierdie "commitment" moet daar besin word. 
Saamgevat meen Wartofsky dan dat die Metafisika gesistematiseerde "common sense" is wat as konsepsuele raamwerk funksioneer in wetenskapsbooefening en op sy beurt begrond die wetenskap weer die kritiek teenoor hierdie "common sense".

Verder wil die Metafisika die weg oopmaak vir 'n kritiek op die grondslae van die "verstaan" in die wetenskappe en daarom moet dit ook selfkritiek beoefen en uiteindelik moet Metafisika die model verskaf vir die wetenskaplike "verstaan" van die dinge.

Dit is duidelik dat Wartofsky meer as Popper en Agassi homself loswikkel van die valse dilemma waarin die Positivisme homself bevind en koester. Wartofsky wil veral in die grondslae van die wetenskappe 'n positiewe geintegreerde rol toeken aan die Metafisika en wil dus 'n sterk regulatiewe en evaluerende en kritiese betekenis verleen aan Metafisika.

Die onderskeid en samehang tussen Wysbegeerte en die wetenskappe

Vooraf is dit nodig dat onomwonde gestel moet word dat die skeiding wat die Positivisme aanbring tussen die wetenskappe en Wysbegeerte (Metafisika) soos ons aangetoon het, op sekere veronderstellings berus wat ons nie kan aanvaar nie. Nie alleen word 'n verte'..nde beeld van die Wysbegecte gegee nie, asof dit ipso facto spekulatief en a-empiries is nie, maar andersyds word die eensydige beklemtoning van die induktiewe metode gehipostaseer na die Wysbegeerte en in die lig daarvan onbruikbaar vind.

Die samehang tussen Wysbegeerte en die vakwetenskappe bestaan in die eerste plek daarin dat Wysbegeerte sowel as die vakwetenskappe die resultaat van wetenskaplike aktiwiteit is en dus as wetenskap moet kwalifiseer. Van die kant van die filosowe kan met reg verwag word om die term Metafisika te laat vaar as daaronder verstaan word dat die Wysbegecte a-empiries of selfs a-recelel is (of irrecell). $\mathrm{Na}$ ons mening het sowel die Wysbegeerte as die vakwetenskappe met die konkrete werklikheid te doen, en omdat dié werklikheid nie eenvormig is nie maar gedifferensieer, bestaan daar verskillende wetenskappe (vakwetenskappe). Sowel Wysbegecrte as die vakwetenskappe is die resultaat van 'n metodiese besinning oor die werklikheid of ' $n$ aspek van die werklikheid as veld van ondersoek en hipoteses/teorieč daaromtrent en die resultaat vertoon dan die tekens van sistematiese struktuur wat as gevolg van die metodiese bewerking van gegewens oor die veld van ondersoek deur die mens tot stand gebring word. Louët Feisser (1962, p. 12) stel dit ondubbelsinnig: "Want van tween dingen eten: of de filosofie is een buitenwetenschappelijke aangelegenheid of zij impliceert een grondslagenonderzoek van de wetenschappen, maar dan kan men onmogelijk haar wetenschappelijk gehalte in twijfel trekken". 
Sowel Wysbegeerte as die vakwetenskappe vertoon dan as wetenskappe 'n duidelike ooreenkoms daarin dat dit aan die eenkant die mens (wetenskaplike) is wat hom vanuit sy religieuse verbondenheid (want daarvan kan hy nie loskom nie) rig op die werklikheid of 'n deel van die werklikheid en teoriec̈ daaroor met behulp van bepaalde metodes.

Die onderskeid tussen Wysbegeerte en die vakwetenskappe op hierdie vlak is dat die vakwetenskappe die veld van hul ondersoek beperk tot 'n besondere aspek van die werklikheid terwyl Wysbegeerte die hele werklikheid in die oog het in sy verskeidenheid en samehang. In hierdie opsig is Wysbegeerte meermale 'n totaliteitswetenskap genoem, iets wat ook vir misverstand vatbaar kan wees. Want dit impliseer nie dat Wysbegeerte belangriker is as die vakwetenskappe nie, maar wel dat dit anders is. Dit stel die geheel voorop en nie die dele soos die vakwetenskappe nie. Hierin lê besondere raakpunte tussen Wysbegeerte en die vakwetenskappe. 'n Klassieke voorbeeld is die verskillende maniere waarop na die hand van 'n mens gekyk kan word, in vergelyking met die voorpoot van 'n aapsoort. Morfologies is daar groot ooreenkoms, en dit is eers wanneer die hand van die mens in die konteks van die menswees bestudeer word dat die verskille duidelik aan die lig kom.

Strauss (1969, p. 12-13) noem die voorbeeld van die verskillende gesigshoeke van die biochemikus en die sitoloog. Eersgenoemde is in die eerste plek geinteresseerd in die fisies-chemiese opboustowwe van die sel, terwyl laasgenoemde byvoorbeeld die tipiese lewensfunksies van die sel sal volg, maar die vakwetenskaplike sal verplig word om sy blik wysgerig "wyer te rig op die samehang van gegewens wat sy blikveld te bowe gaan". Hy kom tot die slotsom: "Die vakwetenskaplike sowel as die wysgerige denke (word) gelydelik gekonfronteer met die transendentale grondprobleem van 'n kritiese deurdenke tot die grense van alle wetenskaplike denkaktiwiteit. Die wysgerige denke se betrokkenheid op die verskeidenheidsamehang en totaliteit van die kosmos, ook in die vakwetenskap - grondleggende gerigtheid daarvan, word tans uitgedryf tot die aanvaarding van 'n eksplisiete (of implisiete) totaliteitsidee wat sal trag om die grense van die wetenskaplike denkwerksaamheid te verantwoord" (p. 13).

Maar daar is ook 'n tweede ooreenkoms. Nie alleen het'sowel die Wysbegecrte as die vakwetenskappe met die konkrete werklikheid te doen nie, maar by albei hierdie soorte van wetenskapsbeoefening speel 'n bepaalde werklikheidsbeskouing, mensbeskouing en kenteorie w.o. weten3kapsbeskouing 'n rol. Dit wil sê by elke filosoof en vakwetenskaplike speel Jaar religieuse grondoortuigings 'n rol wat regulatief en bepalend inwerk op die ontologiese, antropologiese en kenteoretiese grondslae van sowel die 
wysbegeate as die vakwetenskappe.

Elke wetenskaplike, dit wil sê elke filosoof en/of vakwetenskaplike, besit ' $n$ bepaalde werklikheidsbeskouing en al is dit miskien nie volledig gesistematiseer as 'n ontologie nie, dan is die belangrikste elemente wel daarin vervat. Weliswaar is dit die taak van die Wysbegeerte om 'n ontologie te skep of konstrueer, dit wil sê 'n sistematiese beeld van die werklikheid en dit is juis in hierdie verband waar die hulpdienskarakter van die Wysbegeerte vir die vakwetenskaplike sy relevansie toon. Ook die vakwetenskaplike het reeds, soos Radnitzky (1968, p. 391) aantoon, in sy benadering van sy veld van ondersoek sekere "internal steering factors" waaronder die ontologie. En dit is juis op die grens tussen die vakwetenskap en die wysbegeerte waar die vakfilosoof sy staanplek het en waarin dan oor die ontologiese grondslae van die bepaalde wetenskap besin kan word.

Maar op sy beurt is hierdie werklikheidsbeskouing weer gefundeer in sekere religieuse grondoortuigings of "commitments". So sal die calvinistiese vakwetenskaplike en Filosoof stel dat die geskape werklikheid nie sonder die verhouding tot God volledig geken kan word nie omdat die Skrifwoord en die Skeppingswoord op mekaar aangewys is en hul eenheid vind in Christus die Vleesgeworde Woord. Maar die empiris of naturalis gaan 'n heeitemal ander kant uit en wil die werklikheid probeer verklaar vanuit homself en kom dan maklik tot reduksionering van die verskeidenheid van aspekte na cen aspek wat as verklaringsgrond aangebied word. Soms word dit dan met ' $n$ "isme" aangedui byvoorbeeld biologisme, psigologisme, naturalisme ens. Kritiese besinning oor die werklikheidsbeskouings is dus dringend nodig in elke wetenskap. Om slegs een voorbeeld te noem: Watter invloed het die Griekse dualistiese wèreldbeeld nie op verskillende wetenskappe gehad nie? Maar ook ten opsigte van die mensbeskouing is daar 'n sterk aanrakingspunt tussen Wysbegeerte en die vakwetenskappe veral natuurlik die menswetenskappe. Maar ook die Natuurwetenskappe huldig 'n meer of minder geartikuleerde mensbeskouing en daarom sou ons ook kon spreek van die antropologiese grondslae of agtergronde van die wetenskappe. Tradisioneel is die mensbeeld van die positivisme sodanig dat die eenheid van die menslike persoonlikheid verbreek word in sy wetenskapsbeoefening deurdat van hom geëis is om afstand te doen van sy religieuse en ander oortuigings wanneer hy wetenskaplik bedrywig is, in plaas daarvan om hom tot selfkritiek oor sy uitgangspunte te lei.

Volgens die calvinistiese wysgerige antropologie word die mens as eenheidswese beskou en dit beteken dat hy ook in sy wetenskapsbeoefening in 
gebondenheid aan God en sy norme moet handel en dat sy teoretiese arbeid vanuit ' $n$ bepaalde gerigtheid van die hart (Dooyeweerd) geskied of in gehoorsaamheid aan die Skrifwoord. Vir ons doel is dit egter belangrik om te onderstreep dat sekere antropologiese begrondings in verskillende wetenskappe 'n regulatiewe rol speel omdat dit intern funksioneer in die dinamika van wetenskapsbeoefening en wel nie alleen in die evaluering nie, - maar ook in die opstel van nuwe teorieë en/of hipoteses. Ons kan hier verwys na byvoorbeeld die verskillende mensbeelde in die Psigologie, Antropologie, Opvoedkunde, Liggaamlike Opvoedkunde, ens.

Insgelyks is daar ook by sowel die Wysbegeerte as die vakwetenskappe 'n bepaalde kenteoric en/of wetenskapsleer (-beskouing) aanwesig. Net soos in die Wysbegeerte funksioneer daar in die vakwetenskappe ' $n$ bepaalde wetenskapsidee. Hierin gaan dit byvoorbeeld om die doelstellings van die wetenskap, om die motiẹwe van die wetenskaplike om die metodes wat hy gebruik of behoort te gebruik, en om die gebruik van die wetenskap. Die gebrek aan besinning by die vakwetenskappe oor die wetenskapsteoretiese grondslae of fundering van die wetenskappe, het juis gelei tot maklike napratery van die positivistiese wetenskapsideaal. Rombach (1974, p. 11) teken dit goed: "Zwischen Wissenschaft und Wissenschaftstheorie besteht eine enge Verzahnung und ein dynamisches Wechselverhältnis. Je weiter die Wissenschaft vordringt, desto tiefer wird die Wissenschaftstheorie in inhre Reflexionen hineingezwungen, je klarer die wissenschaftstheorethischen Reflexionen die Voraussetzunegn erfassen, desto fähiger wird die Wissenschaft zum präzisierten Vorgriff auf das Seiende." Hy beskuldig die

positivisme juis van dit wat hulle wou bestry: dogmatisme (p. 13). Ons kan die besinning oor die wetenskapsleer nie opeis slegs vir die Wysbegeerte nie, maar moet dit eerder as 'n grensgebied tussen die Wysbegeerte en die vakwetenskappe sien, selfs miskien as 'n interwetenskap (Stoker).

Maar tog is juis die taak van die Wysbegecte om te besin oor die grondstruktuur van kennis en/of wetenskap en kom die diensleweringsfunksie van die Wysbegeerte vir die vakwetenskappe hier ter sprake. In hierdie verband gaan dit om die transendentale voorwaardes van wetenskaplike kennis waarin wel ruimte vir sekere apriori's bestaan. Maar dit is nie moontlik vir die vakwetenskaplike om sonder 'n bepaalde wetenskapsidee te werk nie. Ons noem slegs een voorbeeld. Die seleksie van metodes deur die wetenskaplike word op sy beurt sekerlik bepaal of medebepaal deur sy werklikheidsbeskouing. Wie die kompleksiteit van die werklikheid of sy veld van ondersoek begryp, sal ook begryp dat 'n eensydige metode gebruik in die wetenskap kontrabande is. Daar moet 'n verskeidenheid van metodes 
gebruik word. Rombach voer die pleit vir 'n kritiese wetenskapsidee, wat rekening hou met die verskeidenheid (p. 15). En so wil byvoorbeeld die calvinistiese wetensakpsidee ons daartoe bring om nie alleen plek in te ruim vir die induktiewe en deduktiewe metodes nie, maar ook vir die kontekstuele waarin die veld van ondersoek binne die volle raamwerk gesien word. Daar moet ook plek wees vir wat die perspektiviese metode genoem kan word waarin die wetenskaplike ook perspektiewe gebruik wat nie direk ontleen is aan sy veld van ondersoek nie, maar byvoorbeeld aan die Skrifwoord. Die begrip "Koninkryk van God" in die Skrif wil juis aan ons tuisbring dat alle dinge in verhouding tot God staan, onder sy koningsheerskappy en sy wette wat Hy gegee het. Dit is 'n onmisbare perspektief vir die wetenskappe. So ook byvoorbeeld moet ons besef dat die ganse skepping onder die mag van die kwaad gekom het en dat ons dus in hierdie sin in 'n abnormale werklikheid lewe. Vir die wetenskappe het dit belangrike implikasies.

Hoewel die Wysbegeerte en die vakwetenskappe dus ontologiese, antropologiese en wetenskapsteoretiese grondslae en agtergronde het omdat hulle almal as wetenskappe gekarakteriseer moet word, beklee die Wysbegeerte juis ten opsigte van hierdie aspekte 'n besondere plek. Ons kan hier met Strauss spreek van die funderingsrol van die Wysbegeerte wat onomkeerbaar is of met Louët Feisser wys op die integrerende funksie van die Wysbegeerte via die grondslagondersoekfunksie van die Wysbegeerte. Laasgenoemde stel dit so: "Integratie der wetenschap wordt door de wijsbegeerte bereikt niet door totalisering van alle deelkennis, maar door het grondslagenondersoek, dat alle specialisatie mogejlijk maakt en tevens onderling doet samenhangen" (Louët Feisser, 1962, p. 33).

Ongelukkig stel Louët Feisser na ons mening 'n onnodige teenstelling tussen die totaliteitskarakter van die Wysbegeerte en die grondslagondersoekfunksie daarvan. Die twee aspekte hang ten nouste saam en hoort ook bymekaar.

Dit is nodig dat ons 'n duideliker karakterisering gee van die aksieveld en aard van die Wysbegeerte. Ons kan die veld van ondersoek van die Wysbegeerte omskryf as die grondstrukture van die werklikheid in hul verskeidenheid en samehang. Daarin word veral die klem gelê op die geheelsvisic op die werklikheid maar ook op die terugvragende karakter van die Wysbegeerte (C.A. van Peursen) en ook op die grensprobleme (Van Riessen).

Maar dan kan ons verskillende aksievelde onderskei:

1. Wysbegeerte as wetenskap in eie reg met sy integrale deelwetenskappe of dissiplines soos: Ontologie, Antropologie, Kenteorie w.o. Wetenskapsleer, Geskiedenis van die Wysbegearte. 
2. Wysgerige totaliteitsdissiplines soos Kultuurfilosofie, Staatsfilosofie, Geskiedenisfilosofie, Opvoedingsfilosofie, Natuurfilosofie, Etiek, Logika, Estetika, ens.

Hierdie dissiplines hoort wel by die Wysbegeerte maar tegelyk lewer hulle diens en hulp a an die verskillende vakwetenskappe wat onont beerlik is. By die "vakfilosofieë" gaan dit om vrae na die grense met ander wetenskappe, die grondslae van die wetenskappe, die wysgerige vooronderstellings wat aan bepaalde teorieë ten grondslag lê. Hieronder kan ook Wetenskapsfilosofie of Wetenskapsleer as wysgerige dissipline gereken word waarin die grondstrukture van wetenskaplike kennis bestudeer word, asook die ensiklopediese vraagstukke, die metodologie, ens.

3. Wysbegeerte as gesistematiseerde lewensbeskouing lewer 'n hulpdiens aan die akademiese gemeenskap. Dit gaan hier om die heldere omlynin: van die taak en funksies van die universiteit binne die groter geheel van die mens se roeping vanuit sy lewensbeskoulike verbondenheid. Dit is die taak van die Wysbegeerte om die lewensbeskoulike naelstring bloot te lê en die verhouding daarvan met die gemeenskap van wetenskaplikes te artikuleer om so tot 'n kritiese instelling te lei.

In hierdie verband kan ons weer verwys na Louët Feisser as hy skryf: "Wijsgerend doorvragend naar de grond van het wetenschappelijk vragen, worden wij dus verwezen naar ons zijn in de wereld, dat aan alle bezinning of na-denkende reflectie vooraf gaat en daarvan de vooronderstelling vormt" (Louët Feisser, 1962, p. 24).

4. Wysbegeerte is ook ' $\mathrm{n}$ beinvloedende mag in die samelewing. Juis omdat dit ideologieč, idees, samelewingsteorieë, modelle en strominge bestudeer en evalueer, kry dit ook sig op die kontemporêre problematiek op die verskillende fasette van die breë spektrum van die menslike roeping. Die verband met die akademiese sowel as die agogiese taak van die universiteit is hierin voor-die-hand-liggend. In die akademiese maaltyd wat aan die universiteit as karavaan bedien word, moet hierdie geregte vir gesonde geestelike indigestie nie onderskat en nie aan die student ontsê word nie.

\section{Enkele belangrike implikasies vir die vorming van die student}

1. Die student behoort gesien te word as deel van die akademiese gemeenskap. In hierdie verband verkeer die voorgraadse student nog in 'n adolessente stadium, ook sover dit sy ondervinding van wetenskapsbeoefening betref. Die skepping en opbou van 'n akademiese gemeenskap waarin die student verantwoordelikheid aanvaar om sy deel by te dra tot die totstandkoming van "wetenskap" as metodies gevormde en sistematiese kennis van 'n bepaalde aspek van die werklikheid, mag nie onderskat word nie. 
2. Dit bring mee dat elke student wat die poorte van die akademiese lewe betree nie beskou moet word as 'n tabula rasa nie, maar daar moet rekening gehou word met sy "paradigma" waarmee hy wetenskap wil beoefen. En dit is nodig dat kritiese selfbesinning vroeg reeds begin.

3. Dit is nodig dat elke student ingelei moet word in die ontologiese, antropologiese en wetenskapsteoretiese grondslae van die wetenskapsbeoefening en dat daar dan dus wel 'n duidelike verbinding met Wysbegeerte moet kom. Verskillende universiteite het reeds 'n kursus in Wetenskapsleer ingevoer om hierdie wysgerige materiaal by die student op die tafel te bring. Maar dan is daar meer nodig, naamlik die vakfilosofiese verbindingslyn tussen Wysbegeerte en die vakwetenskappe, laasgenoemde veral in vakgroepverband. Die organiese karakter van die wetenskapsgroepe moet baie sterker beklemtoon word. Daar is byvoorbeeld 'n sterk verbondenheid tussen die historikale wetenskappe, die kultuurwetenskappe, staatswetenskappe, kunswetenskappe, taalkundige wetenskappe ens. En hierdie organiese verbondenheid is te maklik deur die spesialiseringsdrang opsy geskuif tot groot verlies van wetenskaplike daadkrag en besinning. Daarom is die totstandkoming van vakfilosofiese werk in die verskillende vakgroepe nodig en dit van twee kante af naamlik van die kant van die vakwetenskap self en van die kant van die Wysbegeerte.

\section{Samevatting}

Ons kon slegs enkele grepe maak in ons soeke na die betekenis van Wysbegeerte vir die akademiese en persoonlike vorming van die student. Samevattend lyk dit soos volg:

1. Wysbegeerte is onmisbaar binne die universiteit as inrigting vir tersiêre onderwys omdat sodanige onderwys kragtens sy aard filosofies gerig is.

2. In die drie basiese funksies van die universiteit naamlik onderrig, navorsing en opvoeding speel $W y$ sbegecrte ' $n$ rol in sy samehang met en onderskeid van die ander wetenskappe.

3. Die universiteit moet in die beoefening van sy onderrig, navorsing en opvoeding rekening hou met die eenheid van die menslike persoonlikheid en meewerk aan die vorming van 'n geintegreerde persoonlikheid met die oog op 'n wetenskaplik-georiènteerde roepingsvervulling.

4. Die teenstelling tussen Wysbegeerte en vakwetenskappe kan nie gesoek word in die rigting van die positivisme waarin die Wysbegeerte as nie-wetenskaplik gediskwalifiseer word nie. Wysbegeerte is kragtens die karakteristieke eienskappe van die wetenskap ook as 'n wetenskap te beskryf. 
5. Die samehang tussen Wysbegeerte en wetenskappe lê daarin dat albei met die konkrete werklikheid te doen het en met toeriež en standpunte daaroor, dat albei wetenskaplike bewerking van die werklikheid is, dat daar by albei sekere ontologiese, antropologiese en wetenskapsteoretiese agtergronde 'n rol speel.

6. Die onderskeid tussen Wysbegeerte en die vakwetenskappe is daarin geleè dat die Wysbegecrte die werklkheid in sy totaliteit benader en dat hy dus aan die vakwetenskappe agtergronde oopmaak wat onmisbaar is. Maar verder is die onderskeid ook daarin dat daar'n onomkeerbare verhouding is omdat die wysbegeerte aan die vakwetenskappe sekere grondslae kan ontdek en dus op wetenskaplike wyse denkraamwerke daarstel en wetenskaplikes krities wil instel op die hantering van denkraamwerke en vooronderstellings.

7. Die integrasie van die wetenskappe te midde van die spesialisering kan as ' $n$ besondere taak van die Wysbegeerte gesien word.

8. Wysbegecte moet trag om die verbindingslyn te wees tussen groepe wat sterk verwant is aan mekaar. Die totstandbrenging van sodanige vakgroeperinge waarin aandag aan die grondslae gegee word, is nodig juis ook om die gemeenskapskarakter van wetenskapsbeoefening tot sy reg te laat kom.

9. In die lig van bostaande lyk dit my gegewens dat aan elke student (en dosent) ' $n$ oriěntering in wysbegeerte gegee word sodat wetenskaplikes in staat kan wees om die bepaalde werklikheidsbeskouing, mensbeskouing en wetenskapsidee wat in hul onderskeie wetenskappe gehanteer word te onderken en die teorieč van daaruit te evalueer en self nuwe teoriec̈ te ontwerp.

\section{AANGEHAALDE BRONNE}

AGASSI, J. 1964. The nature of scientific problems and their roots in metaphysics. (In: M. Bunge ea. 1964. The critical approach to science and philosophy, Glasgow; Free Press.)

KERR, C. 1969. The modern crisis of the university. (In: Miescher, P.A., red. 1969. The medern university, Stuttgart: Georg Thieme Verlag.)

KONINGSVELD, H. 1977. Het verschijnsel wetenschap, 2de dr. Amsterdam; Boom, Meppel.

LOUËT FEISSER, J.J. 1962. Wetenschap in toga. Utrecht: Oosthoek's Uitg. Mij.

ORTEGA Y GASSET, Jose. 1946. Mission of the university. London: 


\section{Kegan Yaul.}

POPPER, K.R. 1952. The nature of philosophical problems and their roots in science. British journal for the philosophy of science, $3(10)$.

POPPER, K.R. 1968. The logic of scientific discovery. London: Hutchinson.

RADNITZKY, G. 1968. Contemporary schools of metascience. Chicago: Henry Regnery.

ROMBACH, H. e.a. 1974. Wissenschaftsteorie I, Freiburg, Herder.

STRAUSS, D.F.M. 1969. Wysbegeate en vakwetenskap. Bloemfontein: Sacum.

WARTOFSKY, M. 1967. Metaphysics as heuristic for science. (Boston studies in the philosophy of science, III.) Dordrecht. D. Reidel Publishing Co. 